\title{
Effect of Feeding Dried Distiller's Grains Plus Solubles on Milk Yield and its Composition in Dairy Cattle
}

\author{
Sajjan Sihag ${ }^{1}$, Zile Singh Sihag ${ }^{1}$, Sushil Kumar ${ }^{1 *}$ and Narender Singh ${ }^{2}$ \\ ${ }^{1}$ Department of Animal Nutrition, ${ }^{2}$ Department of Livestock Production Management, College \\ of Veterinary Sciences, LUVAS, Hisar-125004, Haryana, India \\ *Corresponding author
}

\begin{tabular}{|l|}
\hline Ke y w o r d s \\
DDGS, Cross bread \\
Cattle, Milk yield, \\
Composition
\end{tabular}

\section{Introduction}

In developing countries like India, the increasing cost and decreasing supply of traditional feedstuffs are expected to constrain the future expansion of livestock production. Feed prices have increased sharply due to increase in the feed ingredient prices. The availability of low-priced, high-quality feeds is critical for the expansion of the dairy industry. DDGS is one of residual coproduced from the production of ethanol from grain after fermentation of the starch (Youssef et al., 2013). The non-fermentable components of this process which are rich in essential nutrients such as protein, fat, fiber, 
vitamins and minerals are recovered in a highly concentrated form (approximately 3 fold) as distillers dried grains with solubles (NRC, 1994; Weigel et al., 1997; AAFCO 2002). DDGS from alcohol industry is a valuable source of energy, protein, water soluble vitamins and minerals for dairy animals. Feed prices have increased sharply due to increase in the feed ingredient prices. DDGS supply energy, protein (amino acids), linolic acid and phosphorus in poultry diet often at a competition price and may lower feed cost (Youssef et al., 2013). Hoffman and Baker (2010) showed that DDGS prices relative to alternate feed ingredients have declined in to a favorable feeding range for many different types of livestock and poultry. Wet and dry distiller's grains are excellent feed ingredients for use in lactating dairy cow rations. Distiller's grains can replace more expensive sources of protein, energy, and minerals in dairy cow diets. Feeding of DDGS to lactating dairy cows has been shown previously to increase the concentration of unsaturated fatty acids in milk fat. Kleinschmit et al., (2006) evaluated the effects of feeding total mixed diets containing $20 \%$ DDGS and found that the DDGS sources used in this study did not affect lactation performance. Anderson et al., (2006) determined the effects of feeding $10 \%$ or $20 \%$ dried or wet distiller's grains with soluble and reported improved feed efficiency and energycorrected milk/kg of DMI by increasing yield of milk, protein, and fat while dry matter intake tended to decrease. Kleinschmit et al., (2007) observed that replacing corn silage with alfalfa hay in diets containing $15 \%$ DDGS increased milk yield, and tended to linearly increase milk protein yield in cows during late lactation. Janicek et al., (2008) suggested that lactating dairy cow rations can contain as much as 30\% DDGS and support satisfactory lactation performance and milk composition. Kalscheur and Garcia (2004) reported that DDGS can be added to growing heifer rations at levels up to $40 \%$ of dry matter intake to achieve excellent growth rate and feed conversion.

Due to increased interest and availability of this feed stuff, the present study has been planned to conduct to evaluate the effect of feeding dried distiller's grains plus solubles on milk yield and its composition in dairy cattle.

\section{Materials and Methods}

The study was conducted at the Lala Lajpat Rai University of Veterinary and Animal Sciences, Hisar, Haryana, India. Sixteen crossbred lactating cattle of average $411.75 \pm 14.23 \mathrm{~kg}$ body weight, $14.01 \pm 1.38$

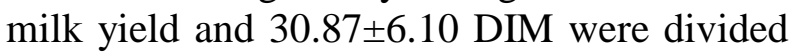
into four treatment groups viz. $T_{1}, T_{2}, T_{3}$ and $\mathrm{T}_{4}$, of four animals each on the basis of milk yield and parity following completely randomized design (CRD). All the experimental cattle were tied with rope in well ventilated feeding stall having arrangement for individual feeding. Before commencement of actual trial animals were acclimatized with experimental feeds for 10 days followed by 115 days of experimental feeding and five days of digestion trial. All the experimental animals were fed weighed quantities of wheat straw, green fodder and concentrate mixture to meet out the requirements as per feeding standards (NRC, 2001). The concentrate mixture of control group $\left(\mathrm{T}_{1}\right)$ was comprised of Maize grain (37), GNC (35), rice polish (25), mineral mixture (2) and common salt (1 part), while, in the concentrate mixture of lactating cattle of treatment groups $\mathrm{T}_{2}, \mathrm{~T}_{3}$ and $\mathrm{T}_{4}$, the $\mathrm{CP}$ of $\mathrm{GNC}$ of control group was replaced with CP of DDGS @ 50, 75, and 100 $\%$, respectively. Ingredient and chemical composition of different concentrate mixtures fed to experimental animals is given in Table 1. The feed intake was recorded at fortnightly intervals on two consecutive days, the average of two days intake was used for daily dry 
matter and crude protein intake. Daily milk yield of morning and evening of individual animal was recorded using digital balance. The milk was sampled at interval of fifteen days for each animal in separate bottles of both morning and evening and mixed before proceeding for estimation of major constituents of milk. Fat and protein percentage were estimated with the help of milk analyzer. Total solids in milk were estimated by Gravimetric method. Fat corrected milk and energy value of milk were calculated by the method of Tyrrel and Reid (1965) by the following formulae:

$4 \% \mathrm{FCM}(\mathrm{Kg})=0.4 \mathrm{x}$ total milk $(\mathrm{kg})+15 \mathrm{x}$ total fat

$\operatorname{EVM}(\mathrm{Mcal} / \mathrm{kg})=0.0929 \times \mathrm{fat} \%+0.0547 \times$ $\mathrm{CP} \%+0.192$

Economics of feeding distiller's dried grains plus soluble as substitute of groundnut cake protein in concentrate mixture of crossbred lactating cattle was calculated. At the end of experimental period a digestion trial of five days was conducted by manual quantitative collection of total faeces from individual animal offered weighed quantity of test diet and recording its refusal. The samples of feed offered, refusals and faeces were analyzed for proximate principles (AOAC, 2005) and fiber fractions (Van Soest et al., 1991).

\section{Results and Discussion}

The chemical analysis of the concentrate mixture revealed that ether extract decreases, while NDF and ADF increases as the level of DDGS increased in the concentrate mixture. The average value of dry matter intake (DMI) per day during the 105 day experimental period was not affected significantly by replacing different levels of groundnut cake with DDGS as primary source of protein in concentrate mixture of lactating cattle. Crude protein intake was increased by the addition of distiller's grains in dairy cow diets. For cattle fed 50 and $100 \%$ DDGS in place of groundnut cake CP intake increased $(\mathrm{P}<0.05)$ as compared to the cattle fed control diets containing no DDGS (Table 3). Dry matter intake of experimental lactating cattle in terms of percent body weight and per $\mathrm{kg}$ metabolic body size (W ${ }^{0.75} \mathrm{~kg}$ ) did not differ significantly among different dietary treatment groups.

No significant difference among control and treatment groups revealed that concentrate mixtures having either groundnut cake or DDGS were equally accepted by the experimental cattle. It was also observed that all the experimental animals were in positive body weight balance and body weight gain of lactating cattle during experimental did not differ significantly due to different replacement levels of GNC with DDGS in their concentrate mixtures (Table 2).

The digestibility of dry matter, crude fibre and NFE, were comparable in all four treatment groups, however, crude protein, ether extract and organic matter digestibility values were significantly $(\mathrm{P}<0.05)$ less in cattle of treatment groups $\mathrm{T}_{3}(75 \%$ DDGS $)$ and $\mathrm{T}_{4}$ $\left(100 \%\right.$ DDGS) as compared to $\mathrm{T}_{1}(0 \%$ DDGS), but these value did not differ significantly among $T_{1}$ and $T_{2}$. The results of study revealed that nutrients digestibility were not affected due to $50 \%$ replacement of ground nut cake with DDGS in concentrate mixture of cattle. The daily digestible crude protein intake and DCP percent value of ration did not differ significantly between treatment groups $\mathrm{T}_{1(0 \% \mathrm{DDGS})}$ and $\mathrm{T}_{2(50 \% \mathrm{DDGS}) \text {, but was }}$ significantly $(\mathrm{P}<0.05)$ less when groundnut cake was replaced at 75 and $100 \%$ level with Dried Distiller's Grain with soluble in concentrate mixture of lactating cattle. 
Table.1 Feed ingredient and chemical composition (\%DM basis) of different concentrate mixtures

\begin{tabular}{|c|c|c|c|c|c|}
\hline \multirow[t]{2}{*}{ Feed ingredient } & \multicolumn{5}{|c|}{ Concentrate mixture } \\
\hline & $\mathbf{T}_{1(0 \% \mathrm{DDGS})}$ & \multicolumn{2}{|l|}{$\mathbf{T}_{2(50 \% \text { DDGS })}$} & $\mathbf{T}_{3(75 \% \text { DDGS })}$ & $\mathrm{T}_{4(100 \% \mathrm{DDGS})}$ \\
\hline Maize & 37.00 & 37.00 & \multicolumn{2}{|c|}{37.00} & 37.00 \\
\hline GNC & 35.00 & 17.50 & \multicolumn{2}{|c|}{08.75} & Nil \\
\hline DDGS & ---- & 17.50 & \multicolumn{2}{|c|}{26.25} & 35.00 \\
\hline Rice Polish & 25.00 & 25.00 & \multicolumn{2}{|c|}{25.00} & 25.00 \\
\hline Mineral Mix. & 02.00 & 02.00 & \multicolumn{2}{|c|}{02.00} & 02.00 \\
\hline CS & 01.00 & 01.00 & \multicolumn{2}{|c|}{01.00} & 01.00 \\
\hline Total & 100.00 & 100.00 & \multicolumn{2}{|c|}{100.00} & 100.00 \\
\hline Cost Rs/Kg & 21.16 & 19.82 & \multicolumn{2}{|c|}{19.16} & 18.50 \\
\hline \multicolumn{6}{|c|}{ Chemical Composition (\% DM Basis) } \\
\hline Attributes & $\mathrm{T}_{1(0 \% \mathrm{DDGS})}$ & $\mathbf{T}_{2(50 \% \mathrm{DDGS})}$ & $\mathbf{T}_{3(75 \% \text { DDGS })}$ & $\mathbf{T}_{4(100 \% \text { DDGS })}$ & DDGS \\
\hline DM & 92.14 & 91.62 & 91.28 & 91.08 & 91.43 \\
\hline $\mathbf{O M}$ & 93.12 & 93.31 & 93.35 & 93.48 & 94.82 \\
\hline $\mathrm{CP}$ & 20.26 & 20.97 & 21.23 & 21.35 & 39.48 \\
\hline EE & 07.59 & 06.77 & 06.36 & 05.94 & 03.62 \\
\hline $\mathrm{CF}$ & 07.16 & 06.98 & 06.66 & 06.41 & 04.01 \\
\hline NFE & 58.11 & 58.59 & 59.10 & 59.78 & 47.71 \\
\hline Ash & 06.88 & 06.69 & 06.65 & 06.52 & 05.18 \\
\hline NDF & 12.03 & 18.19 & 21.28 & 24.36 & 49.24 \\
\hline ADF & 04.76 & 07.63 & 09.05 & 10.49 & 22.37 \\
\hline
\end{tabular}

Table.2 Effect of different levels of DDGS on nutrients digestibility and intake in experimental lactating cattle fed different levels of DDGS

\begin{tabular}{|c|c|c|c|c|c|}
\hline \multirow[t]{2}{*}{ Attribute } & \multicolumn{4}{|c|}{ Dietary treatment } & \multirow[t]{2}{*}{ CD } \\
\hline & $T_{1(0 \% \mathrm{DDGS})}$ & $\mathbf{T}_{2(50 \% \text { DDGS })}$ & $\mathbf{T}_{3(75 \% \mathrm{DDGS})}$ & $\mathbf{T}_{4(100 \% \mathrm{DDGS})}$ & \\
\hline Body wt. changes (kg) & $20.25 \pm 2.25$ & $19.5 \pm 3.20$ & $19.00 \pm 4.02$ & $19.75 \pm 3.25$ & NS \\
\hline DMI(kg)/100Kg body wt & $2.53 \pm 0.07$ & $2.53 \pm 0.02$ & $2.60 \pm 0.05$ & $2.57 \pm 0.12$ & NS \\
\hline DMI (g)/kg W $W^{0.75}$ & $115.29 \pm 2.04$ & $118.48 \pm 1.68$ & $118.31 \pm 1.59$ & $116.63 \pm 4.16$ & NS \\
\hline \multicolumn{6}{|l|}{ Nutrients Digestibility (\%) } \\
\hline DM & $65.95 \pm 0.42$ & $65.69 \pm 0.31$ & $65.22 \pm 0.63$ & $64.37 \pm 0.27$ & NS \\
\hline $\mathbf{O M}$ & $68.62^{\mathrm{a}} \pm 0.23$ & $67.82^{\mathrm{ab}} \pm 0.16$ & $67.26^{\mathrm{b}} \pm 0.62$ & $67.00^{b} \pm 0.22$ & 1.12 \\
\hline $\mathbf{C P}$ & $69.31^{\mathrm{a}} \pm 0.53$ & $68.67^{\mathrm{a}} \pm 0.25$ & $65.41^{\mathrm{b}} \pm 0.32$ & $64.44^{b} \pm 0.29$ & 1.14 \\
\hline $\mathrm{CF}$ & $52.65 \pm 0.51$ & $51.42 \pm 0.63$ & $50.62 \pm 0.64$ & $50.56 \pm 1.01$ & NS \\
\hline $\mathbf{E E}$ & $70.94^{\mathrm{a}} \pm 0.23$ & $68.84^{\mathrm{b}} \pm 0.41$ & $68.25^{\mathrm{b}} \pm 0.13$ & $66.59^{c} \pm 0.26$ & 0.87 \\
\hline NFE & $73.26 \pm 0.31$ & $72.86 \pm 0.31$ & $72.06 \pm 0.57$ & $72.47 \pm 0.14$ & NS \\
\hline \multicolumn{6}{|l|}{ Nutrients Intake } \\
\hline DCPI (g/d) & $969.31^{\mathrm{a}} \pm 10.76$ & $984.69^{\mathrm{a}} \pm 3.15$ & $936.64^{b} \pm 4.73$ & $922.33^{b} \pm 5.27$ & 20.66 \\
\hline TDNI (kg/d) & $7.47^{\mathrm{a}} \pm 0.08$ & $7.51^{\mathrm{a}} \pm 0.06$ & $7.30^{\mathrm{ab}} \pm 0.10$ & $7.22^{\mathrm{b}} \pm 0.04$ & 0.23 \\
\hline \multicolumn{6}{|l|}{ Nutritive value } \\
\hline DCP\% & $8.86^{\mathrm{a}} \pm 0.11$ & $8.77^{\mathrm{a}} \pm 0.05$ & $8.51^{\mathrm{ab}} \pm 0.04$ & $8.45^{\mathrm{b}} \pm 0.07$ & 0.22 \\
\hline TDN\% & $68.35^{\mathrm{a}} \pm 0.31$ & $67.88^{\mathrm{a}} \pm 0.12$ & $66.39^{b} \pm 0.57$ & $66.13^{b} \pm 0.31$ & 1.13 \\
\hline
\end{tabular}

Mean values with different superscripts in a row differ significantly $(\mathrm{P}<0.05)$. 
Table.3 Dry matter intake, milk yield, milk composition and feed efficiency in dairy cattle fed different levels of dried distillers grains with solubles

\begin{tabular}{|c|c|c|c|c|c|}
\hline \multirow[t]{2}{*}{ Attribute } & \multicolumn{4}{|c|}{ Dietary treatment } & \multirow[t]{2}{*}{ CD } \\
\hline & $\mathbf{T}_{1(0 \% \mathrm{DDGS})}$ & $\mathbf{T}_{2(50 \% \mathrm{DDGS})}$ & $\mathbf{T}_{\mathbf{3}(75 \% \mathrm{DDGS})}$ & $\mathbf{T}_{4(100 \% \mathrm{DDGS})}$ & \\
\hline \multicolumn{6}{|l|}{ Intake } \\
\hline DM, kg/d & $10.93 \pm 0.14$ & $11.14 \pm 0.18$ & $10.86 \pm 0.20$ & $10.55 \pm 0.16$ & NS \\
\hline $\mathrm{CP}, \mathrm{kg} / \mathrm{d}$ & $1.51^{\mathrm{a}} \pm 0.01$ & $1.55^{\mathrm{b}} \pm 0.01$ & $1.53^{\mathrm{ab}} \pm 0.01$ & $1.54^{\mathrm{b}} \pm 0.01$ & 0.02 \\
\hline \multicolumn{6}{|l|}{ Production } \\
\hline Milk, kg/d & $14.03^{\mathrm{ab}} \pm 0.65$ & $15.44^{\mathrm{a}} \pm 0.87$ & $13.11^{\mathrm{bc}} \pm 0.40$ & $12.65^{\mathrm{c}} \pm 0.63$ & 2.05 \\
\hline FCM, kg/d & $15.11^{\mathrm{a}} \pm 0.29$ & $16.50^{\mathrm{b}} \pm 0.29$ & $13.78^{c} \pm 0.56$ & $13.21^{\mathrm{c}} \pm 0.31$ & 1.18 \\
\hline \multicolumn{6}{|l|}{ Efficiency } \\
\hline Feed efficiency & $1.39^{\mathrm{a}} \pm 0.02$ & $1.48^{\mathrm{a}} \pm 0.03$ & $1.27^{\mathrm{b}} \pm 0.06$ & $1.26^{\mathrm{b}} \pm 0.02$ & 0.11 \\
\hline $\mathrm{N}$ efficiency $\%$ & $30.73^{\mathrm{ab}} \pm 1.19$ & $32.21^{\mathrm{a}} \pm 1.50$ & $28.62^{b c} \pm 1.41$ & $26.74^{\mathrm{c}} \pm 0.95$ & 3.04 \\
\hline \multicolumn{6}{|l|}{ Milk composition } \\
\hline Fat $\%$ & $4.56^{\mathrm{a}} \pm 0.03$ & $4.47^{\mathrm{ab}} \pm 0.04$ & $4.36^{\mathrm{bc}} \pm 0.07$ & $4.31^{c} \pm 0.02$ & 0.13 \\
\hline Protein \% & $3.35 \pm 0.07$ & $3.28 \pm 0.07$ & $3.34 \pm 0.03$ & $3.31 \pm 0.06$ & NS \\
\hline Total solid \% & $12.64^{\mathrm{a}} \pm 0.06$ & $12.45^{\mathrm{ab}} \pm 0.06$ & $12.34^{\mathrm{b}} \pm 0.08$ & $12.27^{\mathrm{b}} \pm 0.04$ & 0.19 \\
\hline EVM kcal/kg milk & $798.82^{\mathrm{a}} \pm 2.79$ & $786.82^{\mathrm{ab}} \pm 4.69$ & $780.12^{b} \pm 7.31$ & $772.90^{\mathrm{b}} \pm 3.65$ & 15.31 \\
\hline \multicolumn{6}{|l|}{ Feed conversion ratio } \\
\hline DMI, g/kg milk & $782.28 \pm 30.41$ & $727.54 \pm 33.93$ & $857.64 \pm 44.00$ & $864.47 \pm 34.06$ & NS \\
\hline DMI, g/kg FCM & $726.03^{a} \pm 23.74$ & $680.05^{\mathrm{a}} \pm 28.70$ & $811.66^{b} \pm 37.85$ & $827.07^{\mathrm{b}} \pm 23.48$ & 90.45 \\
\hline Cost Rs./Kg FCM & 11.31 & 9.99 & 11.89 & 12.12 & \\
\hline
\end{tabular}

Mean values with different superscripts in a row differ significantly $(\mathrm{P}<0.05)$.

Feed efficiency $=$ FCM/DMI; Nitrogen efficiency $=$ milk N/ N intake.

Similarly, daily TDN intake of experimental cattle and TDN percent in ration were not affected up to $50 \%$ replacement level, however, decreased significantly $(\mathrm{P}<0.05)$ at higher level of substitution of GNC with DDGS (Table 2).

Milk production was not impacted by $50 \%$ substitution of groundnut cake with distiller's grains, but there was a curvilinear response to increasing distiller's grains in crossbred dairy cattle diets (Table 3). Cattle fed diets containing $100 \%$ dried distiller's grains plus soluble in place of GNC, milk yield tended to decrease. These cattle produced $1.38 \mathrm{~kg} / \mathrm{d}$ less milk than cattle fed no distiller's grains. The experimental cattle fed 50\% DDGS substituting GNC as protein source produced higher $(\mathrm{P}<0.05)$ amount of $4 \%$ fat corrected
milk(FCM), approximately $1.39 \mathrm{~kg} / \mathrm{d}$ more, than cows fed diets containing no distiller's grains. When cattle were fed the higher dietary inclusion rate $(75 \& 100 \%$ replacement levels) of distiller's grains had decreased fat corrected milk production.

The average milk fat percentage was higher $(\mathrm{P}<0.05)$ in $\mathrm{T}_{1} \quad(4.56 \pm 0.03)$ than $\mathrm{T}_{3}$ $(4.36 \pm 0.07)$ and $\mathrm{T}_{4}(4.31 \pm 0.02)$, however, did not differ significantly with $\mathrm{T}_{2}(4.47 \pm 0.04)$, similar trends were observed in total solid contents of milk. The results of the study revealed that milk fat and total solids contents are not affected by $50 \%$ replacement of groundnut cake with DDG in concentrate mixture of cattle, however, crude protein contents of milk were not influenced even at $100 \%$ substitution. Milk energy value 
(kcal/kg) did not differ among cattle fed diets GNC based concentrate mixture or containing $50 \%$ DDGS in place of GNC. However, energy value of milk decreased $(\mathrm{P}<0.05)$ by 18 and 26 kcal units per $\mathrm{kg}$ milk when distiller's grains was included at 75 and 100\% as alternate protein source of groundnut cake. Similarly Nitrogen efficiency (milk N/N intake) percent value was higher in cattle fed $50 \%$ GNC and 50\% DDGS $\left(\mathrm{T}_{2}\right)$ followed by control group $\left(\mathrm{T}_{1}\right)$ but did not differ significantly among each other, however, cattle fed $100 \%$ DDGS had significantly $(\mathrm{P}<0.05)$ less nitrogen efficiency as compared to fed no DDGS.

The feed efficiency and feed conversion ratio in terms of feed intake per $\mathrm{kg} 4 \%$ FCM production were not affected at 50\% replacement of groundnut cake with DDGS as protein source in concentrate mixture of lactating cattle. However, at 75 and $100 \%$ substitution levels feed efficiency decreased $(\mathrm{P}<0.05)$ and FCR reduced. There was net saving of Rs. 1.32 feed cost per $\mathrm{kg} \mathrm{4 \% FCM}$ production in cattle by replacing GNC with DDGS at $50 \%$ level.

With no negative effects on the animals among control and treatment groups revealed that concentrate mixtures having either groundnut cake or DDGS were equally accepted by the dairy cattle with more economic returns in the DDGS fed animals.

\section{References}

AAFCO (2002). Official publication of the Association of American Feed Control Officials, Inc. Oxford, IN.

Anderson, J.L., D.J. Schingoethe, K.F. Kalscheur, and A.R. Hippen. 2006. Evaluation of dried and wet distiller's grains included at two concentrations in the diets of lactating dairy cows. J. Dairy Sci. 89:3133-3142.
AOAC (2005). Official Methods of Analysis. $18^{\text {th }}$ edn. Association of Official Analytical Chemists, Gaitherburg, Madison.

Hoffman, L.A. and Baker, A. (2010). Estimating the substitution of distillers' dried grains for corn and soybean meal in the U.S. feed complex. A report from the economic research service by USDA.

Janicek, B.N., P.J. Kononoff, A.M. Gehman, and P.H. Doane. 2008. The effect of feeding dried distiller's grains plus solubles on milk production and excretion of urinary purine derivatives. J. Dairy Sci. 91:3544-3553.

Kalscheur, K.F. and A.D. Garcia. 2004. Use of by-products in growing dairy heifer diets. Extension Extra, South Dakota State University. ExEx 4030, 3 pp.

Kleinschmit, D.H., D.J. Schingoethe, A.R. Hippen, and K.F. Kalscheur. 2007. Dried distillers grains plus solubles with corn silage or alfalfa hay as the primary forage source in dairy cow diets. J. Dairy Sci. 90(12):5587-5599.

Kleinschmit, D.H., D.J. Schingoethe, K.F. Kalscheur, and A.R. Hippen. 2006. Evaluation of various sources of corn dried distiller's grains plus solubles for lactating dairy cattle. J. Dairy Chapter 17. Use of DDGS in Dairy Cattle Diets 12 Sci. 89:4784-4794.

NRC (1994). National Research Council, Nutrient Requirements of Poultry. National Academy of ingredient of poultry diets, World's Science. Washington, D.C.

NRC (2001). National Research Council, Nutrient Requirements of Poultry. National Academy of ingredient of poultry diets, World's Science. Washington, D.C.

Tyrrel, H. F. and Reid, J. T. (1965). Prediction of the energy value of cow's milk. J. Dairy Sci. 48(9):1215-23. 
Van Soest, P.V., Robertson, J.B. and Lewis, B.A. (1991). Methods for dietary fiber, neutral detergent fiber and nonstarch polysaccharides in relation to animal nutrition. J. Dairy Sci. 74: 3583-3597.

Weigel, J.C., Loy, D. and Kilmer, L. (1997). Feed co-products of the dry corn milling process. Renewable Fuels Association and National Corn Growers
Association. Washington, DC, and St. Louis, MO.

Youssef, A.W., Abd-El-Azeem, N.A., ElDaly, E.F. and El-Monairy, M.M. (2013). The impact of feeding graded levels of distillers dried grains with solubles (DDGS) on broiler performance, hematological and histological parameters. Asian J. Poult. Sci. 7(2): 41-54.

\section{How to cite this article:}

Sajjan Sihag, Zile Singh Sihag, Sushil Kumar and Narender Singh. 2018. Effect of Feeding Dried Distiller's Grains Plus Solubles on Milk Yield and Its Composition in Dairy Cattle. Int.J.Curr.Microbiol.App.Sci. 7(03): 1861-1867. doi: https://doi.org/10.20546/ijcmas.2018.703.220 